\title{
PEMBELAJARAN KAIWA BERBASIS JFS CAN-DO
}

\author{
Yeni $^{1}$, N. N. Suartini ${ }^{2}$, I. W. Sadyana ${ }^{3}$, G. S. Hermawan ${ }^{4}$ \\ ${ }^{123} J u r u s a n$ Pendidikan Bahasa Jepang, Universitas Pendidikan Ganesha, Singaraja \\ e-mail: yenirahmansifa@gmail.com, nnsuartini@undiksha.ac.id, \\ wayan.sadyana@undiksha.ac.id, satya.hermawan@undiksha.ac.id
}

\begin{abstract}
Abstrak
Keterampilan berbicara merupakan salah satu dari empat keterampilan berbahasa yang harus dikuasai oleh pembelajar bahasa Jepang. Berbicara adalah sarana untuk menyampaikan ide kepada lawan bicara sehingga maksud dari pembicara dapat tersampaikan. Keterampilan berbicara berkaitan dengan aspek penggunaan bahasa untuk berkomunikasi secara lisan sehingga untuk mengajarkan keterampilan berbicara dilaksanakan pembelajaran kaiwa. Pada tahun 2010 The Japan Foundation memperkenalkan standar baru bagi pendidikan bahasa Jepang yang disebut dengan JF Standard for Japanese-Language Education. JF Standard mempunyai konsep bahasa Jepang untuk pemahaman lintas budaya dengan dua kemampuan yang diperlukan, yaitu kemampuan penyelesaian tugas dan kemampuan pemahaman lintas budaya. JF Standard digunakan untuk mengetahui tingkat kematangan bahasa Jepang dan Can-Do merupakan indikator yang menunjukkan tingkat kematangan bahasa atau pemahaman bahasa yang dimiliki. Berdasarkan latar belakang tersebut, pembelajaran kaiwa dilakukan berbasis JFS Can-Do.
\end{abstract}

Kata kunci: Pembelajaran Kaiwa, Japan Foundation Standard, Can-Do

\begin{abstract}
Speaking skills are one of the four language skills that must be mastered by Japanese language learners. Speaking is a means to convey ideas to the speaker so the intentions of the speaker can be conveyed. Speaking skills relate to aspects of the use of language to communicate verbally so as to teach speaking skills implemented kaiwa learning. In 2010 The Japan Foundation introduced a new standard for Japanese language education called JF Standard for Japanese Language Education. JF Standard has a Japanese concept for cross-cultural understanding with two required abilities, namely the ability to complete tasks and the ability to cross-cultural understanding. JF Standard is used to determine the level of maturity of Japanese and Can-Do is an indicator that shows the level of language maturity or understanding of the language possessed. Based on this background, kaiwa learning is based on JFS Can-Do.
\end{abstract}

Keywords : Kaiwa Learning, Japan Foundation Standard, Can-Do

\section{Pendahuluan}

Ada empat keterampilan berbahasa yang harus dikuasai oleh seseorang yang mempelajari bahasa, yaitu keterampilan menyimak, keterampilan berbicara, keterampilan membaca, dan keterampilan menulis. Keterampilan menyimak dan keterampilan membaca bersifat reseptif sedangkan keterampilan berbicara dan menulis bersifat produktif. Dalam bahasa Jepang empat keterampilan berbahasa disebut dengan istilah kiku ginou (keterampilan menyimak), hanasu ginou (keterampilan berbicara), yomu ginou (keterampilan membaca), dan kaku ginou (keterampilan menulis). Pembelajar bahasa Jepang dituntut untuk menguasai empat keterampilan berbahasa dengan baik agar pembelajar mampu berkomunikasi dengan menggunakan bahasa Jepang secara lisan maupun tulisan (Sutedi, 2009:39). Di antara empat keterampilan berbahasa tersebut, keterampilan berbicara merupakan salah satu keterampilan yang sangat penting untuk dikuasai pembelajar bahasa Jepang karena berkaitan dengan aspek penggunaan bahasa untuk berkomunikasi secara lisan. 
Berbicara adalah sarana untuk menyampaikan ide atau gagasan kepada lawan bicara sehingga maksud dari pembicara dapat tersampaikan. Tarigan (2008:16) menyebutkan bahwa berbicara adalah suatu alat untuk mengkomunikasikan gagasangagasan yang disusun serta dikembangkan sesuai dengan kebutuhan-kebutuhan sang pendengar atau penyimak. Ketika mempelajari bahasa Jepang, seseorang tidak hanya akan belajar menyimak, membaca dan menulis, tetapi juga belajar berbicara. Kemampuan berbicara bahasa Jepang tidak hanya dilihat dari kemampuan seseorang dalam memahami bahasanya saja tetapi juga dilihat dari kemampuan berkomunikasi menggunakan bahasa tersebut. Untuk mengajarkan keterampilan berbicara bahasa Jepang, dilaksanakan pembelajaran kaiwa.

Pada tahun 2010 The Japan Foundation membuat standar baru bagi pendidikan bahasa Jepang yang disebut dengan JF Standard for Japanese-Language Education. JF Standard ini dikembangkan berdasarkan konsep CEFR yang menjadi pondasi pendidikan bahasa-bahasa Eropa. CEFR (Common European of Reference for Language: Learning, teaching assessment) adalah kerangka yang digunakan bersama pada institusi pembelajaran dan pendidikan bahasa-bahasa di Eropa. JF Standard mempunyai konsep, yaitu bahasa Jepang untuk pemahaman lintas budaya. Dalam konsep tersebut diperlukan dua kemampuan, antara lain: kemampuan penyelesaian tugas dan kemampuan pemahaman lintas budaya.

JF Standard digunakan untuk mengetahui tingkat kematangan bahasa Jepang. Berkaitan dengan hal tersebut, Can-Do merupakan indikator yang menunjukkan contoh aktivitas bahasa yang mampu dilakukan pada tingkat kematangan bahasa atau pemahaman bahasa yang dimiliki. Can-Do dinyatakan dengan kalimat "Mampu..." yang menunjukkan tingkat kematangan pencapaian bahasa. Can-Do memiliki enam level, yaitu A1, A2, B1, B2, C1, dan C2. Level A merupakan penggunaan bahasa Jepang dasar (Basic User), level B merupakan penggunaan bahasa Jepang mandiri (Independent User), dan level C merupakan penggunaan bahasa Jepang mahir (Proficient User). Level A1 adalah level terendah dan C2 adalah level tertinggi dalam tingkat kematangan pencapaian bahasa. JF Sandard selalu berkaitan dengan Can-Do sehingga disebut dengan JFS Can-Do. Pada artikel ini akan diuraikan mengenai pembelajaran bahasa berbasis JFS Can-Do yang berfokus pada pembelajaran kaiwa level A2.

\section{Bagian Inti}

Pembelajaran kaiwa berbasis JFS Can-Do mengambil topik tentang “食生活” dengan kategori “情報交換する (やりとり)” pada level A2. Pertama-tama menentukan target pembelajaran (Can-Do) dari topik yang diambil. Tujuan pembelajaran (Can-Do) dapat dibuat sendiri disesuaikan dengan kondisi pada institusi pendidikan masing-masing sehingga disebut My Can-Do. My Can-Do yang dibuat sendiri tetap mengacu pada JF Can-Do yang ada. Pada pembelajaran kaiwa ini target pembelajarannya menggunakan My Can-Do, yaitu (1) Mampu menjawab dengan alasan sederhana [popular No.1] atau [seasonal only] dan bertanya kepada teman orang Jepang tentang masakan yang recommended di restoran, (2) Mampu mengonfirmasi apakah masakannya halal atau tidak dan apa yang terkandung dalam masakannya setelah melihat menu di restoran, (3) Mampu memesan di restoran dengan kosakata sederhana. My Can-Do yang digunakan dalam pembelajaran kaiwa mengambil referensi dari JF Can-Do, antara lain: (1) JF 522 Can ask and or answer questions about simple information, such as the taste and ingredients of dishes one recommends to a friend, for example in a restaurant, (2) JF 379 Can ask a friend questions and answer questions concering simple information such as the types of ingredients used in a typical food (curry etc.) that he/she knows well, (3) JF 328 Can order in short simple terms food, drink, or other things at a restaurant, etc. Pembelajaran kaiwa berbasis JFS Can-Do secara detail dapat dilihat dibawah ini. 


\section{学習目標}

<話す>

(1) レストランで日本人の友人に、おすすめの料理について質問したり、「人気 No1」

「季節限定」などの簡単な理由を挙げて答えたりすることができる。

(2) レストランでメニューを見て、料理に「何が入っているか」「ハラルかどうか」な よ゙を確認することができる。

(3) レストランで短い簡単な言葉で注文することができる。

<異文化の視点>

日本のレストランのメニューに季節限定、ハラルフードなどがあることを意識させ る。

\section{参考にした Can-do 【CEFR or JF 番号 レベル カテゴリー 】}

(1) JF 522 (A2-2 情報交換する)

レストランなどで友人に、おすすめの料理について、味や食材などの簡単な情報 を、質問したり、質問に答えたりすることができる。

(2) JF 379 (A2-2 情報交換する)

相手もよく知っている定番料理（カレーなど）について、使う食材の種類などの

簡単な情報を、友人に質問したり、質問に答えたりすることができる。

(3) JF 328 (A2-2 店や公共機関でやりとりをする)

飲食などで店員に、料理や飲み物などを短い簡単な言葉で注文することができ る。

\begin{tabular}{|c|c|}
\hline \multicolumn{2}{|r|}{ 授業概要 } \\
\hline $\begin{array}{l}\text { 学習者の } \\
\text { 想定レベル }\end{array}$ & A2-2 \\
\hline 想定授業時間 & 50 分 × 2 単位 \\
\hline 主な教材 & $\begin{array}{ll}\text { - } & \text { PPT } \\
\text { ・ } & \text { 絵カード } \\
\text { ・ } & \text { 自己評価シート } \\
\text { ・ } & \text { ビデオ（サイゼリヤりんくうシークル店で撮影） } \\
\text { ・ } & \text { メニュー }\end{array}$ \\
\hline $\begin{array}{l}\text { 参考リソース } \\
\text { 【参考 URL】 }\end{array}$ & $\begin{array}{l}\text { まるごと初級 2-A2 活動 第 } 3 \text { 課 おすすめは何ですか（pp. } \\
\text { 34-39) }\end{array}$ \\
\hline
\end{tabular}

\begin{tabular}{|c|c|c|c|}
\hline $\begin{array}{l}\text { 時間 } \\
\text { (分) }\end{array}$ & \multicolumn{2}{|r|}{ 活動内容 } & 教材 \\
\hline 3 & & 開始挨拶、出席など。（出席簿に記入する） & \\
\hline 5 & $\begin{array}{c}\text { ウォームアッ } \\
\text { プ（スキーマ } \\
\text { の活性化） }\end{array}$ & $\begin{array}{l}\text { 教師はレストランでよく使う言葉や表現は何か。 } \\
\text { 学習者に聞く。 }\end{array}$ & \\
\hline 3 & $\begin{array}{l}\text { 学習目標の } \\
\text { 確認 }\end{array}$ & $\begin{array}{l}\text { 学習目標 Can-do を確認する。 } \\
\text { (1) レストランで日本人の友人に、おすすめの料理 } \\
\text { について質問したり、「人気 No1」「季節限定」 } \\
\text { などの簡単な理由を挙げて答えたりすることが } \\
\text { できる。 } \\
\text { (2) レストランでメニューを見て、料理に「何が入 } \\
\text { っているか」「ハラルかどうか」などを確認す } \\
\text { ることができる。 }\end{array}$ & PPT \\
\hline
\end{tabular}




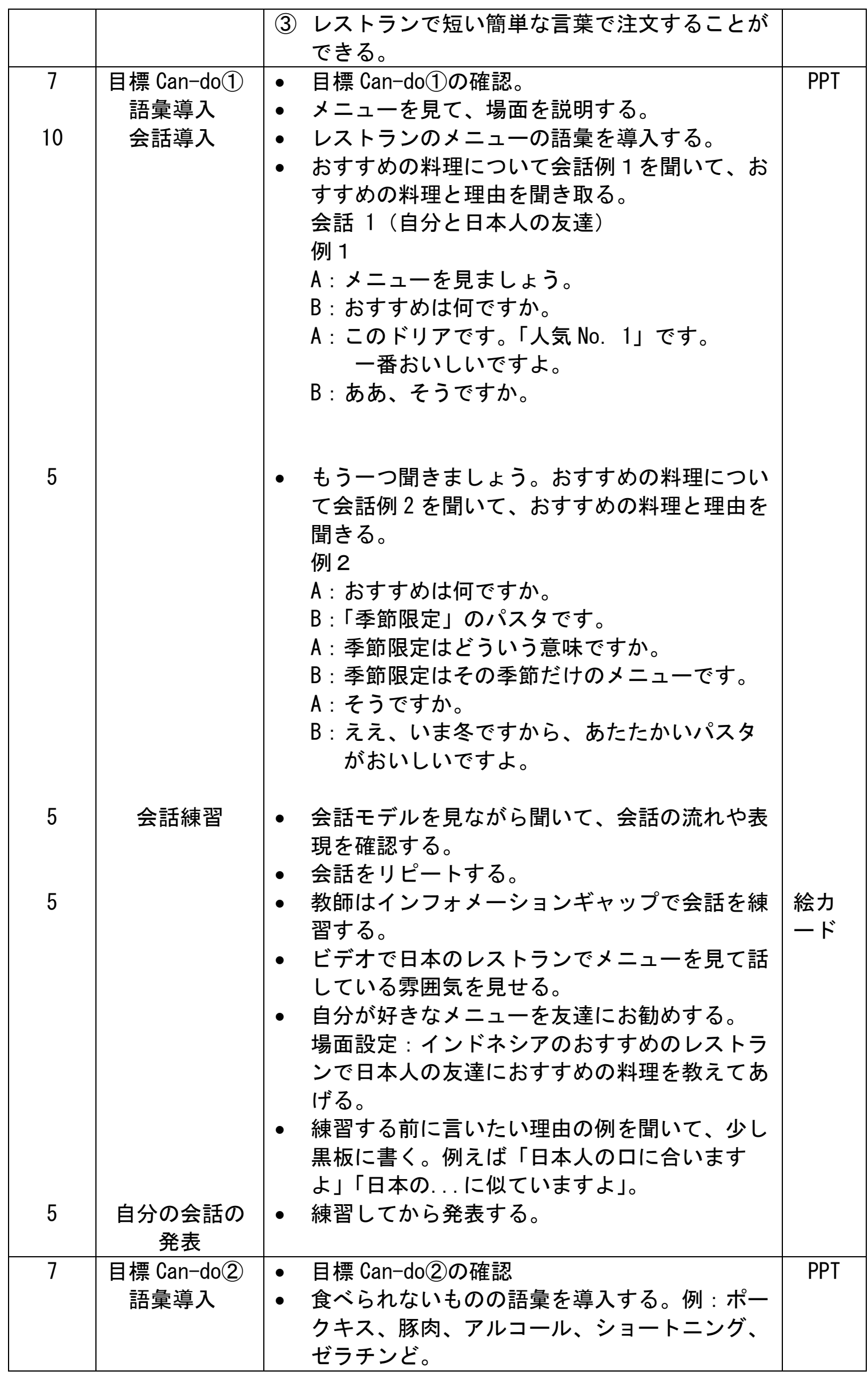




\begin{tabular}{|c|c|c|c|}
\hline 10 & 会話導入 & $\begin{array}{l}\text { ・ レストランのメニューについて会話 } 2 \text { を聞い } \\
\text { て、店員に確認している食べられないものを聞 } \\
\text { き取る。 } \\
\text { 会話 } 2 \text { (メニューを見て、店員さんに食べられ } \\
\text { ないものが入ていないか確認する) } \\
\text { A : あの、すみません。この料理に豚肉が入っ } \\
\text { ていますか。 } \\
\text { C: そうですね。店長に聞いてみます。少々お } \\
\text { 待ちくたさい。 } \\
-\quad----- \\
\text { C : お待たせいたしました。この料理に豚肉は } \\
\text { 入っていません。 } \\
\text { A : そうですか。よかったです。 }\end{array}$ & \\
\hline 5 & $\begin{array}{l}\text { 自分の会話の } \\
\text { 発表 }\end{array}$ & $\begin{array}{l}\text { ・ 会話モデルを見ながら聞いて、会話の流れや表 } \\
\text { 現を確認する。 } \\
\text { ・ 会話をリピートする。 } \\
\text { ・ 教師はインフォメーションギャップで会話を練 } \\
\text { 習する。 } \\
\text { ・ 自分が好きなものを選んで、選んだメニューに } \\
\text { 何が入っているかを店員に確認し、会話をす } \\
\text { る。 } \\
\text { 場面設定 : 日本のレストランでインドネシア人 } \\
\text { が店員に確認する。 }\end{array}$ & 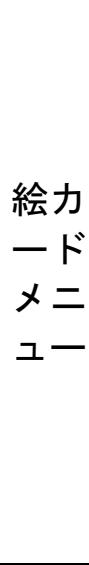 \\
\hline 5 & $\begin{array}{c}\text { 目標 Can-do(3) } \\
\text { 語彙導入 } \\
\text { 会話導入 }\end{array}$ & 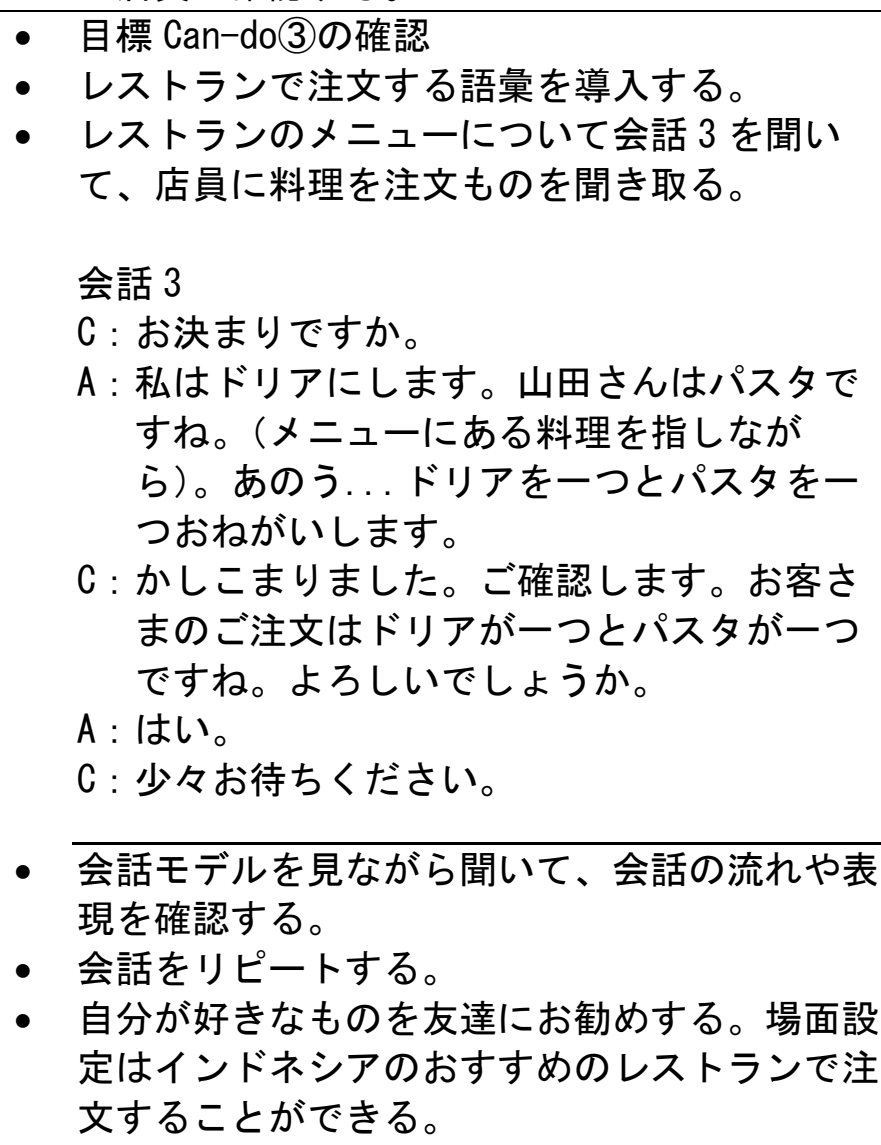 & \\
\hline
\end{tabular}




\begin{tabular}{|c|c|l|l|}
\hline 15 & $\begin{array}{c}\text { 自分の会話の } \\
\text { 発表 }\end{array}$ & $\begin{array}{l}\text { ・練習してから発表する。 } \\
\text { 場面設定 : インドネシア人 } \\
\text { と日本人の友達が日本にあるインドネシア料理 }\end{array}$ & \\
& & $\begin{array}{l}\text { のレストランに行く。目標 Can Do 1，2，3 } \\
\text { をまとめて練習する。 }\end{array}$ & \\
\hline 5 & 自己評価 & 自己評価と振り返り & 自己 \\
& & & 評価 \\
& & & シー \\
& & & ト \\
\hline
\end{tabular}

Pembelajaran kaiwa berbasis JFS Can-Do ini untuk pembelajar bahasa Jepang level A2-2 dengan alokasi waktu 100 menit. Bahan ajar dan media ajar yang dipakai antara lain: PPT, kartu gambar, lembar penilaian diri, video restoran, dan menu. Sumber referensi yang digunakan, yaitu Marugoto Shokyuu 2-A2, Katsudou, Dai 3 ka Osusume wa nan desu ka (pp. 34-39).

Pada pembelajaran kaiwa berbasis JFS Can-Do ini pertama-tama dilakukan warming up (導入), yaitu pengajar bertanya kepada pembelajar kosakata dan ungkapan apa yang sering digunakan di restoran. Setelah itu, pengajar mengonfirmasi tujuan pembelajaran (Can-Do). Tujuan pembelajaran (Can-Do) ada 3, yaitu (1) Can-Do 1 : Mampu menjawab dengan alasan sederhana [popular No.1] atau [seasonal only] dan bertanya kepada teman orang Jepang tentang masakan yang recommended di restoran, (2) Can-Do 2: Mampu mengonfirmasi apakah masakannya halal atau tidak dan apa yang terkandung dalam masakannya setelah melihat menu di restoran, (3) Can-Do 3: Mampu memesan di restoran dengan kosakata sederhana.

Bagian awal pembelajaran kaiwa, pengajar terlebih dahulu menjelaskan kepada pembelajar tujuan pembelajaran pertama (Can-Do 1), yaitu mampu menjawab dengan alasan sederhana [popular No.1] atau [seasonal only] dan bertanya kepada teman orang Jepang tentang masakan yang recommended di restoran. Tahap pengantar (導入) pengajar mengenalkan kosakata yang ada di menu restoran kemudian dilanjutkan dengan memperdengarkan contoh kaiwa 1 dan contoh kaiwa 2 tentang masakan yang recommended disertai alasannya. Pembelajar menyimak contoh percakapan/kaiwa yang diperlihatkan oleh pengajar kemudian pembelajar menyebutkan masakan yang recommended dan alasannya apa berdasarkan informasi yang didapat dari kaiwa yang diperdengarkan. Tahap latihan dasar (基本練習) pengajar menunjukkan model kaiwa kepada pembelajar dan mengonfirmasi ungkapan dan alur percakapannya kemudian pembelajar mengulang kaiwa yang ditunjukkan. Tahap selanjutnya adalah latihan penerapan (応用練習), yaitu pembelajar melakukan latihan percakapan dari percakapan yang telah dibuat sendiri dengan setting adegan (場面設定) yang ditentukan oleh pengajar. Setting adegan yang digunakan adalah memberitahu masakan yang recommended disertai alasan kepada teman orang Jepang di restoran Indonesia yang recommended. Setelah semua tahapan pembelajaran kaiwa untuk Can-Do 1 tuntas, dilanjutkan pembelajaran kaiwa untuk Can-Do 2.

Pengajar menjelasakan tujuan pembelajaran kedua (Can-Do 2), yaitu mampu mengonfirmasi apakah masakannya halal atau tidak dan apa yang terkandung dalam masakannya setelah melihat menu di restoran. Pada tahap pengantar (導入) pengajar mengenalkan kosakata mengenai makanan yang tidak boleh dimakan seperti ekstrak babi, daging babi, alkohol, gelatin, dan lain-lain. Kemudian pengajar memperlihatkan contoh kaiwa tentang mengonfirmasi kepada pelayan restoran menu yang tidak dapat dimakan dan pembelajar menyimak kaiwa tersebut. Tahap selanjutnya latihan dasar (基本練習) pengajar menunjukkan model kaiwa kepada pembelajar dan mengonfirmasi ungkapan dan alur percakapannya kemudian pembelajar mengulang kaiwa yang ditunjukkan. Setelah itu, pada tahap latihan penerapan (応用練習) pembelajar melakukan latihan percakapan dari percakapan yang telah dibuat sendiri dengan setting adegan (場面設定) yang ditentukan 
oleh pengajar. Setting adegan yang digunakan, yaitu orang Indonesia mengonfirmasi kepada pelayan di restoran Jepang apa yang terkandung dalam masakan di menu yang dipilihnya. Pembelajaran kaiwa untuk Can-Do 2 tuntas kemudian dilanjutkan pembelajaran kaiwa untuk Can-Do 3.

Pengajar menjelaskan tujuan pembelajaran ketiga (Can-Do 3), yaitu mampu memesan di restoran dengan kosakata sederhana. Tahap pengantar (導入) pengajar mengenalkan kosakata untuk memesan di restoran dan memperlihatkan contoh kaiwa tentang cara memesan masakan kepada pelayan di restoran kemudian pembelajar menyimak contoh kaiwa tersebut. Tahap latihan dasar (基本練習) pengajar menunjukkan model kaiwa kepada pembelajar dan mengonfirmasi ungkapan dan alur percakapannya kemudian pembelajar mengulang kaiwa yang ditunjukkan. Selanjutnya, tahap latihan penerapan (応用練習) pembelajar melakukan latihan percakapan dari percakapan yang telah dibuat sendiri dengan setting adegan (場面設定) yang ditentukan oleh pengajar. Setting adegannya adalah orang Indonesia dan teman orang Jepang pergi ke restoran masakan Indonesia yang ada di Jepang kemudian memesan masakan di restoran tersebut. Latihan ini sekaligus berlatih percakapan menggunakan Can-Do 1, 2, dan 3 secara keseluruhan.

Di bagian akhir pembelajaran kaiwa berbasis JFS Can-Do dilakukan penilaian diri (自 己評価) dan refleksi (振り返り). Penilaian diri adalah penilaian yang dilakukan oleh pembelajar sendiri untuk mengukur tercapainya target pembelajaran (Can-Do). Saat melakukan penilaian diri sekaligus dilakukan refleksi untuk meninjau kembali proses pembelajaran sebagai upaya perbaikan pembelajaran selanjutnya. Penilaian diri menggunakan lembar penilaian diri (自己評価シート) seperti contoh di bawah ini.

\section{自己評価シート}

\section{目標 Can-Do}

1.レストランなどで日本人の友人に、おす寸めの料理について質問したり、「人気 No1」 と「季節限定」などの簡単な理由を挙げて答えたりすることができる。

2.レストランでメニューを見て、料理に「何が入っているか」「ハラルかどうか」などを 確認することができる。

3.レストランで短い簡単な言葉で注文することができる。

\section{Can-Do チェック}

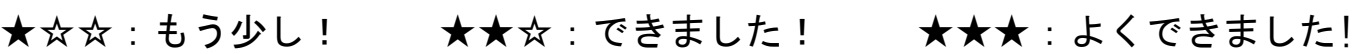

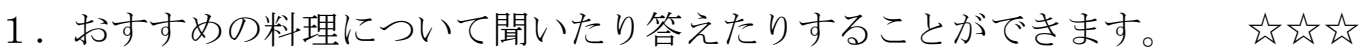

2. 食べられないものについて確認できます。放放

3.レストランで注文できます。放放

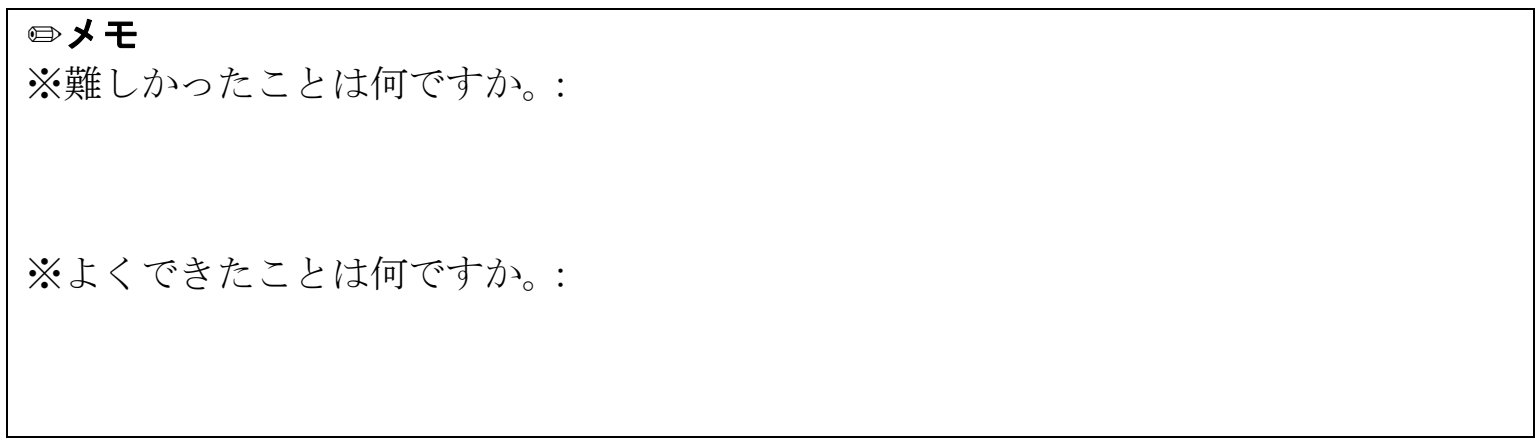

自分に大切な言葉 
Lembar penilain diri di atas berisi antara lain: (1) Tujuan pembelajaran (目標 Can-Do). Pembelajaran kaiwa ini memiliki 3 Can-Do, yaitu Can-Do 1, Can-Do 2, dan Can-Do 3, (2) Can-Do Check (Can-Do チェック) yang memuat pernyataan もう少し/berusaha sedikit lagi (ネ), できました/bisa $(\star \star)$, dan よくできました/bisa melakukan dengan baik $(\star \star \star)$. Pembelajar dapat mengukur sendiri seberapa jauh dapat mencapai target pembelajaran (Can-Do) dengan cara mengisi bintang yang sesuai dengan kemampuan pembelajar pada tema yang ada, (3) Memo yang memuat pertanyaan tentang hal yang sulit dan hal yang bisa dilakukan dengan baik oleh pembelajar. Dengan menuliskan memo ini pembelajar dapat mengetahui kekurangan dan kelebihannya di bagian mana, (4) Kosakata yang penting bagi diri sendiri. Pendataan kosakata yang dianggap penting bagi pembelajar dapat digunakan untuk mengukur penguasaan kosakata.

Secara keseluruhan dari pembelajaran kaiwa berbasis JFS Can-Do yang telah diuraikan di atas terdapat kemampuan penyelesaian tugas, yaitu melakukan sesuatu dengan menggunakan bahasa Jepang atau aktivitas penggunaan bahasa Jepang itu sendiri secara nyata melalui kegiatan berinteraksi berupa percakapan/kaiwa. Selain itu, terdapat pula pemahaman lintas budaya, yaitu kesadaran ada hal yang berbeda seperti halal food dan seasonal only di menu restoran Jepang. Dengan adanya pemahaman lintas budaya ini dapat digunakan untuk memahami dan menghormati kebudayaan orang lain. Pembelajaran kaiwa berbasis JFS Can-Do dapat meningkatkan keterampilan berbicara bahasa Jepang pembelajar.

\section{Ringkasan}

Pembelajaran kaiwa berbasis JFS Can-Do menekankan pada kemampuan penyelesaian tugas (kemampuan menggunakan bahasa) dan kemampuan pemahaman lintas budaya (memahami dan menghormati kebudayaan orang lain dengan melakukan interaksi terhadap berbagai kebudayaan dan meluaskan wawasan). JF Standard digunakan untuk mengetahui tingkat kematangan bahasa Jepang pembelajar dengan Can-Do sebagai indikator yang menunjukkan tingkat kematangan bahasa atau pemahaman bahasa yang dimiliki. Can-Do dibagi menjadi enam level, yaitu A1, A2, B1, B2, C1, dan C2. Level A1 merupakan level terendah dan C2 merupakan level tertinggi dalam tingkat kematangan pencapaian bahasa. Setiap proses pembelajaran berbahasa berbasis JF Standard penting untuk dilakukan refleksi (振り返り) sebagai upaya perbaikan pembelajaran di masa yang akan datang. Selain itu, penilaian diri juga penting dilakukan oleh pembelajar sendiri untuk mengukur tercapainya target pembelajaran (Can-Do).

\section{Daftar Pustaka}

Susanti, R. 2018. Self Evaluation JFS (Japan Foundation Standard) Can-Do in the Lesson of Kaiwa IV Minna no Nihongo. Proceeding International Conference of Japanese Language Education (ICoJLE), 19-20 Oktober 2018. Hal. 139-145.

Sutedi, D. 2009. Penelitian Pendidikan Bahasa Jepang. Bandung: Humaniora.

Tarigan, H.G. 2008. Berbicara sebagai suatu Keterampilan Berbahasa. Bandung: Angkasa.

The Japan Foundation. 2016. Marugoto Bahasa dan Kebudayaan Jepang A2 Aktivitas. Jakarta: Kesaint Blanc.

The Japan Foundation. 2017. JF Standard bagi Pendidikan Bahasa Jepang: Petunjuk Pemakaian bagi Pengguna (Edisi Terbaru). Jakarta: The Japan Foundation. 